\title{
Petrology and geochemistry of the Muntele Mare granitoid (Northern Apuseni Mountains), Romania
}

\author{
Lucreţia GHERGARI ${ }^{*}$, Cristina MARIŞ² \\ ${ }^{1}$ Department of Mineralogy, "Babeş-Bolyai”" University, Kogălniceanu 1, 400084 Cluj Napoca, Romania \\ ${ }^{2}$ S.C. Cominex Nemetalifere S.A., Principală 1, 407145 Căpuşu Mare, Romania
}

Received September 2005; accepted March 2007

Available online 30 August 2007

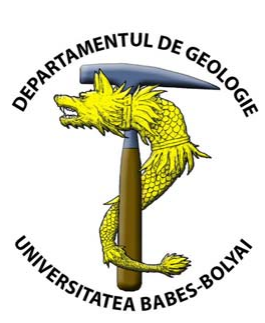

\begin{abstract}
The paper brings new data on the petrography and geochemistry of the Muntele Mare Granitoid (MMG), from its northernmost outcropping area (Mănăstireni-Bedeci area, Gilău Massif, Apuseni Mountains), where $M M \backslash G$ is are actively quarried for quartz and feldspar that are used in the ceramics industry. The MMG mined in the Bedeci quarry has a pegmatitic hypidiomorphous - inequigranular fabric, and a low melanocratic index (ca. 7\%). It consists of quartz, plagioclase (two generations: acidic andesine-basic oligoclase (34-35\% An), and albite $(9-11 \% \mathrm{An}))$, orthoclase \pm perthite in various substitution stages by microcline (intermediary), as well as microcline maximum, muscovite and biotite. Accessories include: apatite, zircon, magnetite, rutile and titanite. Garnets occur in contact areas, and local concentrations of apatite and tourmaline are found in areas affected by metasomatic processes. Micas underwent micronization, iron leaching and hydration. Three textural varieties are identified: equigranular, microgranular, and gneissic granite. Subsequent alkaline metasomatism, cataclastic deformation, and silicification transformed these varieties into a pegmatitic granite. The contact of the MMG with the overlying Someş lithogroup is marked by a $0.5-1.0 \mathrm{~m}$ thick biotite hornfels. Away from the contact, the hornfels gradually turns into granitic gneiss affected by metasomatic processes. The major element distribution in the Bedeci Valley granitoid is characteristic to a peraluminous, subalkaline, medium-potassic granite, affected by dominantly sodic alkaline metasomatism, and $\mathrm{Al}$ enrichment. Geochemical processing of the analytical data (major elements; 296 samples) suggests that the granite has been formed in a collision environment, which contrasts with the post-collision environment inferred by other authors. We state that this contradiction is to be explained by chemistry changes caused by metasomatism and silicification processes.
\end{abstract}

Keywords: Petrography, geochemistry, sodium metasomatism, cataclastic and silicification processes, Muntele Mare Granitoid, Northern Apuseni Mts., Romania.

\section{INTRODUCTION}

The 330-295 Ma old Upper Carboniferous-Lower Permian Muntele Mare Granitoid (MMG) is the largest intrusive body in the Apuseni Mountains (Pană, 1998; Balintoni et al., in prep.). Its emplacement mechanism has been the subject of some debate in the Romanian geological literature. It was initially described as a batolith by Dimitrescu (1966), but later authors (Borcoş et al., 1968; Ianovici et al., 1976), and Dimitrescu (1988)), agreed on its phacolithic shape. Dimitrescu (1994) considers the MMG to be hosted into a SW dipping anticlinal fold of the Someş lithogroup, thus contradicting the structural model of Hârtopanu et al. (1982) of a synclinal megafold in the area.

The Precambrian mesometamorphic rocks of the Someş lithogroup in which the MMG intruded constitute the autochtonous Bihor Unit of the Apuseni Mountains. They underwent three metamorphic events (Hârtopanu et al., 1982; Strusievicz and Strusievicz, 1985; Dimitrescu, 1988). The first two events, M1 (kyanite and staurolite), and M2 (sillimanite \pm andalusite) are prograde, whereas M3 is retromorphic, (chlorite+actinote+sericite) and has a limited extent, along certain alignments. During the M2 event, both the Someş and the overlying Gârda lithogroup were affected by extensive migmatic processes, and the Arieş granitoids were emplaced (Anton, 1999; Balintoni et al., in prep.). The emplacement of migmatites and pegmatite bodies in the mega-anticline fold area (Trif et al., 1966; Mârza, 1980), even if of a different origin, can be temporally correlated with the Muntele Mare granitoid (Balintoni et al., in prep.).

Based on petrographic criteria, several rock types have been grouped under the generic "Muntele Mare granite" name: equigranular granites (typically located in the central part of the massif), microgranular granites, porphyry granites, gneissic granites, cataclastic granites, and pegmatitic granites (Stoicovici and Trif, 1961; Hanomolo and Hanomolo, 1962).

In the study area the MMG is covered by rocks of the Someş lithogroup, in which it intruded. In places where these rocks have been eroded, the MMG comes in direct contact with Paleogene sedimentary rocks (Fig. 1). In these areas the MMG is sometimes exposed only in valley beds. This is the case of Călata Valley in the Western part of the studied area, as well as of the upper course of Căpuş Valley (Bedeci Valley) in the E. At Bedeci, the MMG is quarried for quartz and feldspar that are used as raw materials in the ceramics industry.

\section{SAMPLES AND METHODS}

In the Bedeci area the MMG crops out on both sides of the valley. Several open-pit mines are used as sources for granite (quartz and feldspar) in Bedeci, and for quartz in 
Mănăstireni. The quarry blocks in the Bedeci quarry are number-coded. This study is based on samples collected from blocks 3, 4, 5, 7, 8, 9, 14, 15, 16, 16/2, 17, 40, 49; one additional sample was collected from the Racilor Valley. Petrographic investigations have been carried out on 23 granite and metamorphic rock samples, collected as follows: six from block 16, four from block 6 , one from block 15 , two from block 14, two from block 4, two from the access road (downstream of the quarry) and six from upstream the quarry.

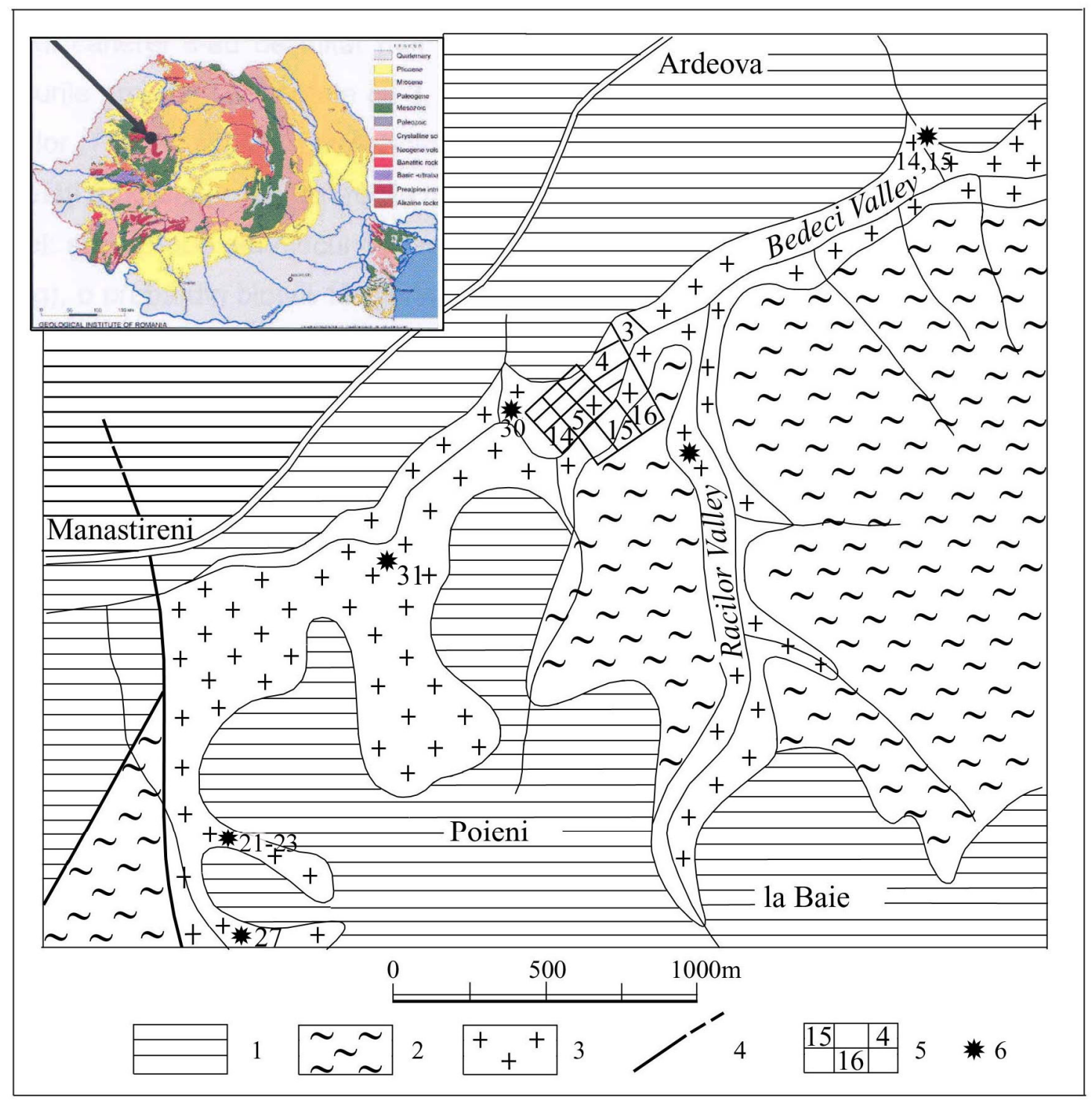

Fig. 1. Geologic map of the Bedeci area (based on the geological map of S.C. Transgex S.A. Cluj Napoca, modif.); 1. Paleogene; 2. Someş lithogroup (Precambrian); 3. Muntele Mare Granitoid (330-295 m.y.); 4. Fault; 5. Quarry blocks; 6. Sample location.

Petrographic-microscopic studies were performed at "Babes-Bolyai" University in Cluj using a Nikon SMZ645 binocular, a Nikon Eclipse E200 Pol transmission polarising microscope, and a Jena universal stage. Chemical data were obtained at the Chemical Laboratory of the S.C. Cominex Nemetalifere S.A., Căpuş through wet chemical analysis, flamephotometry, and X-ray fluorescence (Venus 100 unit) at Cesarom Bucharest. Structural data (triclinicity of microcline) was calculated from XRD measurements performed on a Bruker D8 Advance diffractometer $(40 \mathrm{kV}$ and $40 \mathrm{~mA}, \mathrm{Cu}$ anticathode: $\lambda=1.540600 \AA$; scanned interval: $\left.4-64^{\circ} 2 \theta\right)$.

\section{MINERALOGY AND PETROGRAPHY}

The mineralogy and petrography of both the granite and the contact metamorphic rocks are discussed below.

\section{The Granite}

Several macroscopic textural varieties (equigranular, microgranular, gneissic and cataclastic) were identified in the study area. The areas in which rocks underwent a cataclastic metamorphism, always display a quartz vein system. Under microscope, the granite is characterised by a hypidiomorphous inequigranular (pegmatitic) structure, with massive to cataclastic or schistose fabric (Plate I, Figs. 1, 2, 3 , and 4).

The main minerals are quartz, $\mathrm{K}$ - and $\mathrm{Ca}-\mathrm{Na}$-feldspars, muscovite and iron-depleted biotite, whereas typical accessories include microlites of apatite, rare zircon crystals, magnetite, rutile, titanite and garnets. In rare cases, apatite appears as well developed crystals, associated with tourmaline. These are inferred to derive from metasomatic processes at the expense of feldspars. Secondary minerals have been formed through alteration of feldspars (kaolinite 
and illite), and micas (illite, chlorite, Fe and Ti oxides). Limonite is common along fissures in the rock.

\section{Quartz}

Two quartz generations have been identified. Firstgeneration quartz is anhedral and has faint undulatory extinction, and sometimes-obvious Boehm planes. Secondgeneration quartz fills a network of veins in granites that underwent cataclastic metamorphism. The latter quartz crystals are usually interlocked (a dynamic effect pointing to injections of fluids under pressure), and lack undulatory extinction or oriented inclusions (Boehm planes).

\section{K-feldspar}

The optical characteristics of K-feldspars vary from sample to sample, or even within the same sample, suggesting several feldspar formation stages. Some of the optical and structural characteristics were probably induced by the mechanical strain associated with the cataclastic metamorphism. Three K-feldspar varieties were separated: slightly modified (triclinic), sometimes perthitic orthoclase; triclinized orthoclase (intermediary microcline); maximum microcline with or without polysynthetically twinned albite separations. Using the measured $\mathrm{Ng}^{\wedge}(010)$ optic angle, only two generations of $\mathrm{K}$-feldspar could be separated: orthoclase I and orthoclase II (i.e. intermediary microcline) in Table 1. The intermediary microcline was defined based on its structural parameters (triclinicity) calculated from XRD patterns. Feldspars from 8 industrial granite samples (enriched with feldspars by specific processing methods, i.e., removal of quartz, micas and mafic minerals) have also been investigated. Two ranges $(0.48-0.56$, and $0.64-0.72)$ were obtained for the triclinicity values, both being typical for intermediary microcline (Mariş, 2005). Within the slightly kaolinized orthoclase crystals that have been investigated we have found muscovite lamellae and rare albite inclusions.

\section{Plagioclase}

Plagioclase also belongs to two generations: twinned crystals with cloudy surfaces and frequent marginal overgrowths represent the first one, with the crystal cores corresponding to acidic andesine, whereas the overgrowths consist of basic oligoclase. The second generation plagioclase (albitic) occurs as anhedral, untwinned crystals formed at the expense of orthoclase through sodic metasomatism (Table 1).

\section{Micas}

Muscovite is lamellar to tabular, with the fringes often altered to a sericite-illite microlamellar aggregate. Biotite is almost completely iron-depleted, with strings of iron and titanium oxides lining the cleavage planes. Only rare chloritised biotite lamellae display weak pleochroism.

Among the accessory minerals, apatite is the most common; zircon is subordinate, while tourmaline (small, highly pleochroic crystals), garnet, magnetite, rutile and titanite are rare. In some samples, carbonates (calcite and siderite) are associated with late, hydrothermal quartz.

The percentages of minerals have a wide range in the investigated granite samples (Table 2). As a whole, the granite has a low melanocratic index (about 7\%).
The MMG from Bedeci area underwent intense alkaline metasomatism, cataclastic and silicification processes. The alkaline metasomatism was dominantly sodic - with formation of albite, and only subordinately potassic, resulting in microcline neoformation. Micas were also significantly affected by transformation processes, i.e., iron depletion (biotite) and sericitization. Upstream from the quarry, the observed metasomatic processes are less intense, the rock turning to gneissic, muscovitic granite.

\section{Contact phenomena}

The thermal contact area of the granite can be observed in the upper part of the quarry - blocks 16 and 6, where it produced true hornfelses (sample 6), and local feldspatisation (samples 5 and 11).

The influence of contact-related hydrothermal fluids can also be noticed further away from the contact, where the biotite from the garnet micaschists underwent iron leaching and chloritization (sample 14).

\section{Biotite Hornfelses}

A brownish black biotite hornfels, about $0.5-1 \mathrm{~m}$ thick, occurs at the contact with the granite. The rock consists mainly of quartz, biotite and muscovite, along with secondary clay minerals, oxides (magnetite and ilmenite), goethite in sphaerulitic aggregates, and subordinate apatite, zircon, tourmaline, rutile, and titanite. Biotite is strongly pleochroic. Quartz forms anhedral crystal aggregates. Clay minerals are formed at the expense of anhedral orthoclase crystals (Pl. I, Fig. 5).

\section{Granitic gneiss}

Granitic gneisses are present further away from the contact area. The rock is granolepidoblastic and has schistose texture, with cataclastic zones (Pl. I, Fig. 6). The paleosome consists of biotite-muscovite-garnet gneiss; the biotite is iron-depleted, with iron and titanium oxides lining cleavage planes and crystal surfaces. The neosome contains (sometimes perthitic) orthoclase, albite with fine muscovite lamellae, and interlocking quartz crystals. The 'augen' consists of orthoclase with frequent muscovite lamellae, apatite, polysynthetically twinned plagioclase and quartz microlites. Overgrowths on feldspar crystals are common. The rock also contains apatite, tourmaline, magnetite and ilmenite. The paleosome plagioclase is basic oligoclase acidic andesine, whereas the one in the neosome is albitic (Table 1).

\section{MAJOR ELEMENT GEOCHEMISTRY}

The geochemical study of the MMG in the Bedeci area aims at:

1. Documenting the alkaline metasomatism and silicification processes that affected the northern extremity of the granitoid by comparing its chemistry with that of samples from the central, unaffected area (Table 3).

2. Presenting a geochemical characterization of the granitoid based on a large number (296) of technological samples. The new chemical data hereby presented statistically reflects the average chemical composition of the granitoid cropping out in the Bedeci - Mănăstireni perimeter (Table 4). 
Table 1. Feldspar composition and optical properties.

\begin{tabular}{|l|c|c|c|c|c|c|}
\hline \multicolumn{2}{|c|}{ PEGMATITIC GRANITE } & \multicolumn{3}{c|}{ GNEISSIC GRANITE } \\
\hline \multicolumn{1}{|c|}{ Mineral } & An $\%$ & $2 \mathrm{~V}$ & $\mathrm{Ng}-(010)$ & $\mathrm{An} \%$ & $2 \mathrm{~V}$ & $\mathrm{Ng}-(010)$ \\
\hline Orthoclase I & & $(-) 60-68$ & $3-4^{\circ}$ & & & \\
\hline Orthoclase II & & $(-) 62-70$ & $8-19^{\circ}$ & & & \\
\hline Plagioclase I & $34-35$ & $(-) 82-86$ & & $25-35$ & $(-) 83-89$ & \\
\hline Plagioclase II & $8-12$ & $(+) 77-82$ & & $0-4$ & $(+) 70-72$ & \\
\hline
\end{tabular}

Table 2. Mineral composition of the pegmatitic granite.

\begin{tabular}{|c|c|c|c|}
\hline Mineral & Range (\%) & Average (\%) & Size $(\mathrm{mm})$ \\
\hline K-feldspar & $10-40$ & 25 & $0.05-8$ \\
\hline Apatite & $0.2-0.8$ & 0.5 & $0.01-0.08$ \\
\hline Iron and titanium oxides & $0.2-0.8$ & 0.5 & $0.005-0.08$ \\
\hline Other minerals* & $0-1$ & 0.5 & \\
\hline
\end{tabular}

Table 3. Chemical composition of samples from the northern extremity (Bedeci-Manastireni area) compared to the central part of the Muntele Mare granitoid.

\begin{tabular}{|c|c|c|c|c|c|c|c|c|c|c|c|c|}
\hline \multirow{2}{*}{ Sample/block } & \multicolumn{12}{|c|}{ Oxide (wt\%) } \\
\hline & $\mathrm{SiO}_{2}$ & $\mathrm{TiO}_{2}$ & $\mathrm{Al}_{2} \mathrm{O}_{3}$ & $\mathrm{Fe}_{2} \mathrm{O}_{3} *$ & $\mathrm{MnO}$ & $\mathrm{MgO}$ & $\mathrm{CaO}$ & $\mathrm{K}_{2} \mathrm{O}$ & $\mathrm{Na}_{2} \mathrm{O}$ & $\mathrm{P}_{2} \mathrm{O}_{5}$ & L.O.I. & Total \\
\hline \multicolumn{13}{|c|}{ Granitoids from Bedeci-Mănăstireni area } \\
\hline $3 / 16$ & 65.31 & 0.01 & 21.15 & 0.28 & 0.01 & 0.09 & 0.67 & 4.36 & 7.23 & 0.04 & 0.74 & 99.89 \\
\hline $4 / 16$ & 71.41 & 0.02 & 16.93 & 0.40 & n.d. & 0.18 & 0.39 & 4.22 & 5.64 & n.d. & 0.80 & 99.99 \\
\hline $5 / 16$ & 73.14 & 0.01 & 15.49 & 0.50 & n.d. & 0.14 & 0.64 & 4.18 & 4.92 & n.d. & 0.99 & 100.01 \\
\hline $7 / 6$ & 77.09 & 0.01 & 13.26 & 0.63 & 0.03 & 0.14 & 0.81 & 3.06 & 3.81 & 0.03 & 0.88 & 99.75 \\
\hline $12 / 4$ & 74.81 & 0.08 & 15.00 & 1.03 & 0.02 & 0.29 & 0.48 & 2.94 & 4.22 & 0.05 & 0.82 & 99.74 \\
\hline $30 / 14$ & 72.04 & 0.01 & 15.60 & 0.40 & 0.02 & 0.10 & 0.37 & 8.17 & 2.12 & 0.04 & 0.63 & 99.50 \\
\hline 23 & 75.47 & 0.03 & 14.75 & 0.73 & 0.01 & 0.15 & 0.55 & 2.81 & 4.34 & 0.03 & 0.78 & 99.65 \\
\hline 27 & 85.75 & 0.01 & 9.81 & 0.33 & 0.01 & 0.08 & 0.32 & 2.23 & 2.35 & 0.03 & 0.54 & 100.46 \\
\hline 31 & 75.38 & 0.11 & 14.31 & 1.05 & n.d. & 0.20 & 0.46 & 3.73 & 3.65 & 0.11 & 1.11 & 100.11 \\
\hline \multicolumn{13}{|c|}{ Central part of the Muntele Mare Granitoid - reference data ** } \\
\hline $1 \mathrm{a}$ & 68.83 & 0.43 & 14.88 & 4.18 & 0.07 & 1.16 & 2.90 & 2.81 & 4.12 & 0.22 & 0.59 & 100.19 \\
\hline $2 \mathrm{a}$ & 65.83 & 0.98 & 17.67 & 5.36 & 0.07 & 0.40 & 2.16 & 2.66 & 4.20 & 0.36 & 1.21 & 100.90 \\
\hline $3 \mathrm{a}$ & 72.42 & 0.23 & 13.72 & 2.75 & 0.04 & 0.88 & 1.44 & 4.76 & 2.96 & 0.10 & 1.30 & 100.60 \\
\hline $4 a$ & 70.61 & 0.45 & 13.71 & 3.32 & 0.06 & 1.07 & 1.86 & 4.74 & 3.11 & 0.23 & 0.91 & 100.07 \\
\hline $5 a$ & 72.52 & 0.29 & 12.00 & 1.88 & 0.14 & 4.10 & 1.01 & 1.77 & 4.85 & 0.17 & 1.46 & 100.19 \\
\hline
\end{tabular}

n.d. $=$ not determined

* total Fe;

** 1a: Granite, Devii Valley (Dimitrescu, 1966); 2a: Gneissic granite, Vadului Valley, and 3a: granite, Dumitreasa Mountain (Borcoş and Borcoş, 1962);

4a: Granite, Răcătăului Valley, and 5a: porphyroid granite, Someşul Rece Valley (Hanomolo and Hanomolo, 1962).

Table 4. Chemical composition of the MMG from Bedeci grouped by quarry blocks.

\begin{tabular}{|c|c|c|c|c|c|c|c|c|}
\hline \multirow{2}{*}{$\begin{array}{l}\text { Quarrying block } \\
\text { (no. of samples) }\end{array}$} & \multicolumn{8}{|c|}{$\begin{array}{c}\text { Oxide wt. } \% \\
\text { (average / minimum-maximum values) }\end{array}$} \\
\hline & $\mathrm{SiO}_{2}$ & $\mathrm{Al}_{2} \mathrm{O}_{3}$ & $\mathrm{Fe}_{2} \mathrm{O}_{3}$ & $\mathrm{MgO}$ & $\mathrm{CaO}$ & $\mathrm{K}_{2} \mathrm{O}$ & $\mathrm{Na}_{2} \mathrm{O}$ & L.O.I. \\
\hline $3(24)$ & 73.23 & 15.68 & 0.595 & 0.46 & 0.88 & 3.38 & 4.84 & 0.92 \\
\hline \multirow{2}{*}{$4(34)$} & 73.21 & 15.69 & 0.57 & 0.39 & 0.92 & 3.84 & 4.43 & 0.87 \\
\hline & $72.24-75.20$ & $14.50-16.87$ & $0.46-0.70$ & $0.20-0.50$ & $0.70-1.55$ & $3.00-5.00$ & $3.60-5.20$ & $0.70-1.06$ \\
\hline \multirow{2}{*}{$5(32)$} & 74.14 & 15.05 & 0.65 & 0.44 & 0.88 & 3.82 & 4.14 & 0.78 \\
\hline & $73.00-75.67$ & $14.00-15.80$ & $0.58-0.72$ & $0.15-0.90$ & $0.80-1.00$ & $3.00-4.39$ & $3.60-4.99$ & $0.34-1.15$ \\
\hline $7(4)$ & 74.55 & 14.80 & 0.65 & 0.50 & 0.90 & 4.00 & 3.90 & 0.70 \\
\hline \multirow{2}{*}{$8(32)$} & 73.42 & 15.59 & 0.64 & 0.39 & 0.85 & 3.81 & 4.40 & 0.90 \\
\hline & $72.46-75.06$ & $14.27-16.20$ & $0.54-0.75$ & $0.15-0.50$ & $0.80-0.98$ & $2.40-5.40$ & $2.80-6.00$ & $0.80-1.00$ \\
\hline \multirow{2}{*}{$14(12)$} & 73.51 & 15.80 & 0.68 & 0.40 & 0.80 & 3.70 & 4.27 & 0.87 \\
\hline & $73.25-73.68$ & $15.60-16.00$ & $0.65-0.70$ & 0.40 & 0.80 & $3.30-4.00$ & $4.10-4.50$ & $0.80-0.90$ \\
\hline \multirow{2}{*}{$15(34)$} & 73.76 & 15.59 & 0.68 & 0.43 & 0.85 & 3.59 & 4.17 & 0.92 \\
\hline & $73.17-75.05$ & $14.70-16.00$ & $0.55-0.77$ & $0.25-0.50$ & $0.56-0.90$ & $3.00-4.30$ & $3.60-4.80$ & $0.80-1.00$ \\
\hline $16(36)$ & 73.84 & 15.29 & 0.64 & 0.50 & 0.88 & 3.61 & 4.28 & 0.89 \\
\hline \multirow{2}{*}{$40(32)$} & 74.70 & 14.74 & 0.73 & 0.43 & 0.82 & 3.75 & 3.94 & 0.91 \\
\hline & $73.20-75.40$ & $14.20-15.50$ & $0.65-0.78$ & $0.15-0.50$ & $0.70-0.98$ & $3.40-4.13$ & $3.60-4.50$ & $0.80-1.06$ \\
\hline \multirow{2}{*}{$49(32)$} & 74.16 & 15.24 & 0.68 & 0.42 & 0.87 & 3.44 & 4.29 & 0.89 \\
\hline & $73.10-75.30$ & $14.52-15.80$ & $0.60-0.80$ & $0.30-0.55$ & $0.80-0.91$ & $3.00-4.00$ & $3.76-5.00$ & $0.70-1.00$ \\
\hline \multirow{2}{*}{ Raci Valley (24) } & 74.20 & 15.34 & 0.62 & 0.39 & 0.79 & 3.44 & 4.36 & 0.87 \\
\hline & $73.00-75.50$ & $14.00-16.20$ & $0.40-0.75$ & $0.25-0.50$ & $0.55-0.90$ & $3.00-4.00$ & $3.50-5.00$ & $0.80-1.00$ \\
\hline
\end{tabular}




\section{Geochemical evidence for alkaline metasomatism and} silicification

The geochemical study is based on samples collected from several locations in the Bedeci (samples 3, 4, 5, 7, 12, 30), and Mănăstireni (samples 23, 27) quarries, as well as from the area situated between the two quarries (sample 31). Our study shows that the rocks from the Bedeci quarry were affected by both alkaline metasomatism and silicification, whereas those in the Mănăstireni quarry mainly underwent silicification. The chemical composition of the analyzed samples is presented in Table 3, along with that of 5 samples from the central part of the MMG taken from the literature (three granites, one gneissic granite and a porphyroid granite.

Binary distribution diagrams are used in order to reveal the chemical changes in the granitoid.

The diagrams of $\mathrm{SiO}_{2}$ vs. $\mathrm{Al}_{2} \mathrm{O}_{3}, \mathrm{Na}_{2} \mathrm{O}$ show a reverse correlation for both oxide pairs (Figs. 2 and 3). It can also be noticed that the samples are plotting along two distinct alignments: one corresponding to higher values for $\mathrm{Na}$ and $\mathrm{Al}$ oxides (the samples from Bedeci-Mănăstireni area, and the porphyroid granite, all affected by intense Na metasomatism), and one corresponding to lower values (samples from the central part of the MMG, not affected by metasomatism).

The $\mathrm{SiO}_{2}-\mathrm{K}_{2} \mathrm{O}$ diagram (Fig. 4) shows no obvious correlation trends between the samples from the two areas. Only two samples, i.e., sample 27 (silicified) and sample 30 (K metasomatism) plot in eccentric positions. Sample 30 shows peculiar low $\mathrm{Na}$ and high $\mathrm{K}$ contents, as a proof of potassic metasomatism (neoformation of microcline). Potassium content is not a discriminating factor for the samples under study, no matter of their degree of $\mathrm{Na}$ metasomatism; this is an additional proof for the $\mathrm{Na}$ metasomatic processes that affected the rocks.

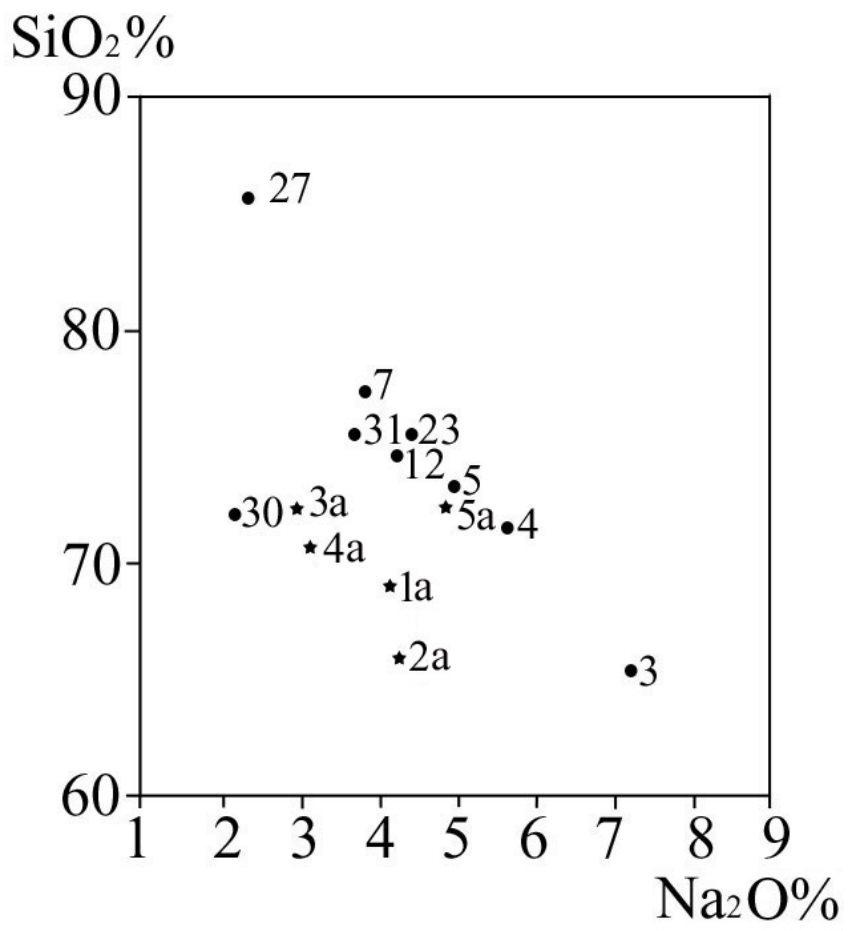

Fig. 2. $\mathrm{SiO}_{2}$ vs. $\mathrm{Na}_{2} \mathrm{O}$ geochemical discrimination diagram for samples from the northern extremity (•) compared to the central part (*) of the Muntele Mare Granitoid.
$\mathrm{SiO}_{2} \%$

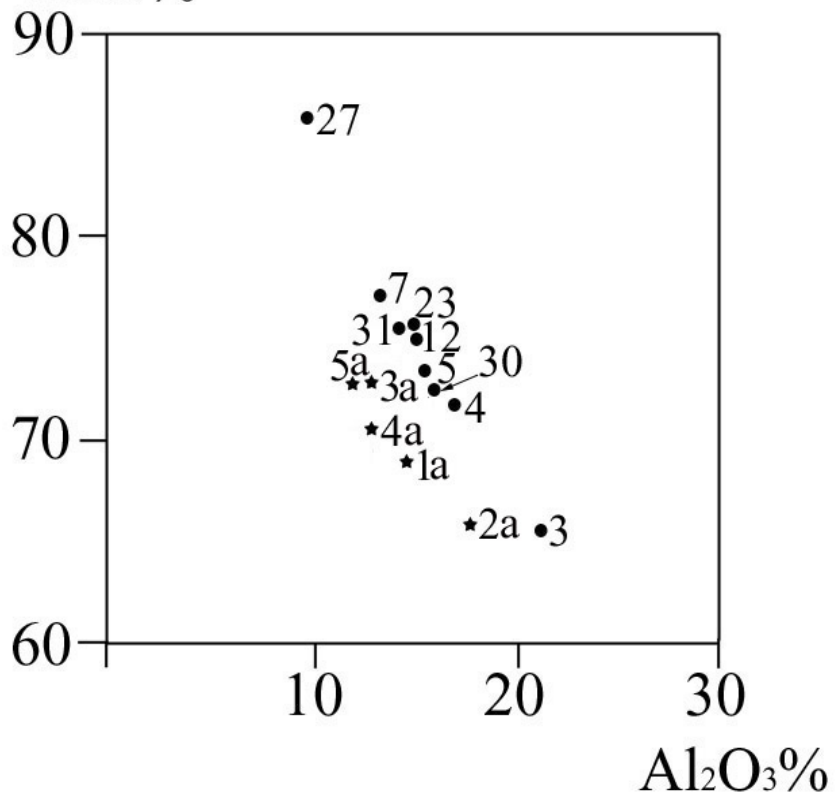

Fig. 3. $\mathrm{SiO}_{2}$ vs. $\mathrm{Al}_{2} \mathrm{O}_{3}$ geochemical discrimination diagram for samples from the northern extremity ( $\bullet$ compared to the central part (*) of the Muntele Mare Granitoid.

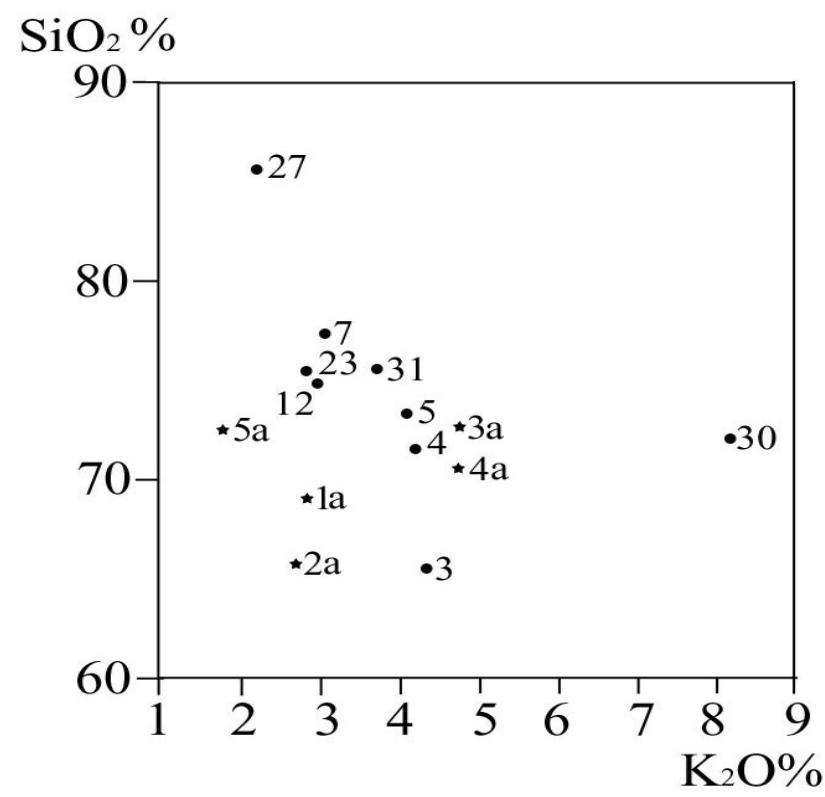

Fig. 4. $\mathrm{SiO}_{2}$ vs. $\mathrm{K}_{2} \mathrm{O}$ geochemical discrimination diagram for samples from the northern extremity $(\bullet)$ compared to the central part (*) of the Muntele Mare Granitoid.

\section{Geochemical characterization of the MMG from the Bedeci area}

The geochemical characterization of the MMG from Bedeci is based on the average chemical composition of the quarry blocks. Table 4 includes these average values, along with the minimum-maximum values for each oxide.

The geotectonic diagrams of MMG from Bedeci area Figs. 5 and 6 - reveal similar plotting of the samples into a restricted area, based on their homogeneous chemistry.

The $\mathrm{A} / \mathrm{NK}$ versus $\mathrm{A} / \mathrm{CNK}$ diagram clearly illustrates the peraluminous nature of all analysed samples (Fig. 5).

In the diagram of Batchelor and Bowden (1985) the same samples cluster in the syn-collision field, while two samples 
from the central area of the MMG (samples $1 \mathrm{a}$ and $2 \mathrm{a}$ in Table 3) plot closer to the post-collision field (Fig. 6). In order to decide if the MMG formation was a syncollision or a post-collision one, we should have supplemental data on the percentage of trace elements. Still, our main goal in this paper was to reveal the metasomatic process that induced chemical transformation in the MMG.

Nevertheless, we intend to investigate these aspects in our future work.

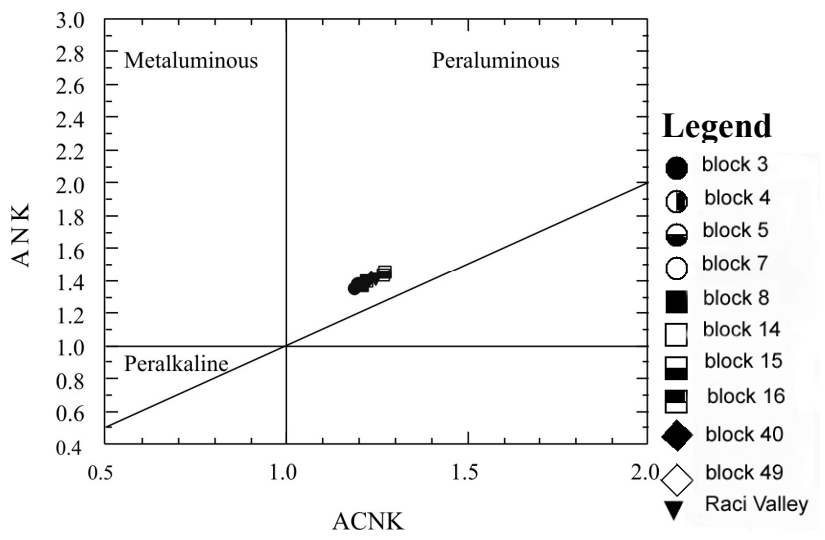

Fig. 5. Plot of investigated granites in Maniar and Piccoli's (1989) discrimination diagram. The coordinates represent ratios ( $A / C N K$ and respectively $A / N K$ ) between molar values of $\mathrm{A}=\mathrm{Al}_{2} \mathrm{O}_{3} ; \mathrm{C}=\mathrm{CaO} ; \mathrm{N}=\mathrm{Na}_{2} \mathrm{O} ; \mathrm{K}=\mathrm{K}_{2} \mathrm{O}$.

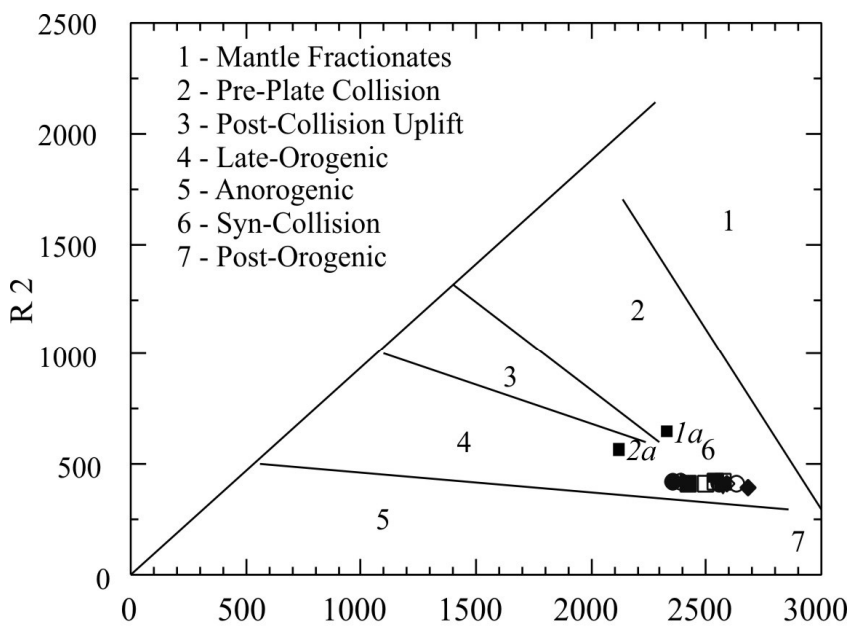

R1

Fig. 6. Plot of investigated samples in Batchelor and Bowden's (1985) geotectonic discrimination diagram. $R I=4 S i-11(\mathrm{Na}+\mathrm{K})$ $2(\mathrm{Fe}+\mathrm{Ti}) ; \mathrm{R2}=6 \mathrm{Ca}+2 \mathrm{Mg}+\mathrm{Al}$.

\section{CONCLUSIONS}

The MMG from the Bedeci-Mănăstireni area is composed of two generations of quartz, two generations of plagioclase (acidic andesine - basic oligoclase, and albite), orthoclase \pm perthite, intermediary microcline (triclinicity: $0.48-0.56$, and 0.64-0.72, respectively), microcline maximum, muscovite, and biotite. Apatite, zircon, tourmaline, garnet, magnetite, rutile and titanite are accessory and post-magmatic minerals.

The analysed rocks have a low melanocratic index (about $7 \%$ ) and a peraluminous, subalkaline, and medium-potassic character. The structure is subhedral inequigranular, with three identifiable varieties: "normal" inequigranular granite, microgranular granite and gneissic granite.
The above-mentioned rock varieties underwent alkaline, predominantly sodic, metasomatism and cataclastic metamorphism, followed by silicification. These processes led to textural transitions of the granite towards pegmatite.

Sodic metasomatism leads to the formation of albite (9-11\% An), whereas the formation of microcline maximum is consquent to potassic metasomatism. The metasomatic, cataclastic and silicification processes also produced mica micronization and iron depletion of biotite.

The present paper mentions and documents the sodic metasomatism of the MMG in the investigated area for the first time. When compared to samples from the central area of the MMG, the samples from the study area clearly reflect enrichment in $\mathrm{Na}, \mathrm{Al}$, and $\mathrm{Si}$, as a result of alkaline metasomatism and silicification.

Contact phenomena led to biotite enrichment in the rocks close to the granite (biotite hornfels), and, in conjunction with the partial removal of quartz and feldspar, contributed to the local increase of the proportion of melanocrate minerals. Granitic gneisses are formed by feldspar enrichment of garnet micaschists next to the biotite-rich area.

The influence of contact-derived fluids is also noticeable further away from the contact zone, where biotite in the micaschists was altered to chlorite.

When plotted in the geotectonic discrimination diagram of Batchelor and Bowden (1985), our samples suggest the granite to be formed in a syn-collision environment. This finding is in contrast with the post-collision environment previously considered for the bulk of the MMG (Balintoni et al., in prep.), but this contradiction could be explained by the changes of the original chemistry induced by alkaline metasomatism and silicification processes. Still, we question if metasomatic processes as those described here could not be characteristic for granites emplaced in a syn-collision environment?

Acknowledgements. We acknowledge the helpful discussions we had with Drs. Ioan Balintoni and Nicolae Har in the Department of Mineralogy, "Babeş-Bolyai" University. Drs. Dana Pop and Tudor Tămaş of the same department are acknowledged for the English translation. We thank Drs. Ştefan Nicolescu and Robert Strusievicz for their significant contribution to the improvement of the manuscript.

\section{R E F E R E N C E S}

Anton, D.C. 1999, Petrographical, geochemical and isotopic study of Mt. Mare granitoids, North Apuseni Mountains Evolution of peraluminous magma. $\mathrm{PhD}$ Thesis, Tokyo Univ., $163 \mathrm{p}$.

Balintoni, I., Balica, C., Cliveti, M., Li, L-Q., Hann, H., P. \& Fukun, C. The intrusion age of the Muntele Mare Variscan granite (Apuseni Mountains) (in preparation).

Balintoni, I., Balica, C., Cliveti, M., Li, L-Q., Hann, H., P., Fukun, C. \& Ghergari, L. Someş terrane, a new Cadomian entity in the Apuseni Mountains, Romania (in preparation).

Batchelor, R.A., Bowden, P. 1985, Petrogenetic interpretation of granitoid rock series using multicationic parameters. Chemical Geology, 48: 43-55.

Borcoş, M., Dimitrescu, R. \& Hanomolo, I. 1968, Contribuții la cunoaşterea structurii masivului granitic Muntele Mare, Dări de Seamă ale Şedințelor Institutului de Geologie şi Geofizică, LIII (3): 5-22. 
Borcoş, M., Borcoş, E. 1962, Cercetări geologice şi petrografice în regiunea Runc - Segagea - Valea Ierii sat (bazinul văii Iara, Munții Apuseni). Dări de Seamă ale Institutului Geologic, XLVII: 131-144.

Dimitrescu, R. 1966, Muntele Mare. Studiu geologic şi petrografic. Anuarul Comitetului de Stat al Geologiei, XXXV: 165-258.

Dimitrescu, R. 1988, Note sur la structure du cristallin "autochtone" du Gilău de sud-ouest. Dări de Seamă ale Şedințelor Institutului de Geologie si Geofizică, 72-73 (5): 75-83.

Dimitrescu, R. 1994, Structura părții centrale a munților Gilăului. Studii şi Cercetări de Geologie, 39: 3-6.

Hanomolo, I.M., Hanomolo, A. 1962, Geologia şi petrografia regiunii Someş - Muntele Rece - Măguri - Mănăstireni Căpuş. Dări de Seamă ale Şedințelor Comitetului Geologic, XLVII: 97-116.

Hârtopanu, I., Balintoni, I., Borcoş, M., Lupu, M. \& Rusu, A. 1982, Harta geologică a României, 1:50000, Foaia Valea Ierii. Institutul de Geologie şi Geofizică, Bucureşti.

Ianovici, V., Borcoş, M., Bleahu, M., Patrulius, D., Lupu, M., Dimitrescu, R. \& Savu, H. 1976. Geologia Munților Apuseni. Editura Academiei R.S.R., Bucureşti, 631 p.

Maniar, P.D., Piccoli, P.M. 1989, Tectonic Discrimination of Granitoids. Geological Society of America Bulletin, 101: 635-643.
Mariş, C. 2005, Mineralogia diferitelor materii prime cuarțofeldspatice şi influența lor asupra proprietăților structurale şi compoziționale ale produselor ceramice. Unpublished $\mathrm{PhD}$ Thesis, "Babeş-Bolyai" Univeristy, Cluj Napoca, Romania.

Mârza, I. 1980, Considérations génétiques sur les pegmatites du cristallin de Gilău (Monts Apuseni) et la province pegmatitique carpatique. Anuarul Institutului de Geologie şi Geofizică, LVII: 423-432.

Pană, D.I. 1998, Petrogenesis and tectonics of the basement rocks of the Apuseni mountains: significance for the alpine tectonics of the Carpathian-Pannonian region. Unpubl. PhD Thesis, University of Alberta, Canada.

Stoicovici, E., Trif, A. 1961, Contribuții la cunoaşterea granitizării în regiunea Muntele Mare - Munții Gilăului. Studia Universitatis Babeş-Bolyai, Ser. II (1): 71-82.

Strusievicz, R., Strusievicz, E. 1985, Asupra prezenței rutilului şi andaluzitului în pegmatitele metamorfice ale seriei de Someş din Munții Plopiş (Munții Apuseni). Dări de Seamă ale Şedințelor Institutului de Geologie şi Geofizică, LXIX (1): 31-38.

Trif, A., Stoicovici, E. 1966, Anatectitul şi migmatitele din bazinul superior al văii Ierii - Cristalinul Gilăului (III). Studia Universitatis Babeş-Bolyai, Geologia-Geographia, 1: 37-54. 

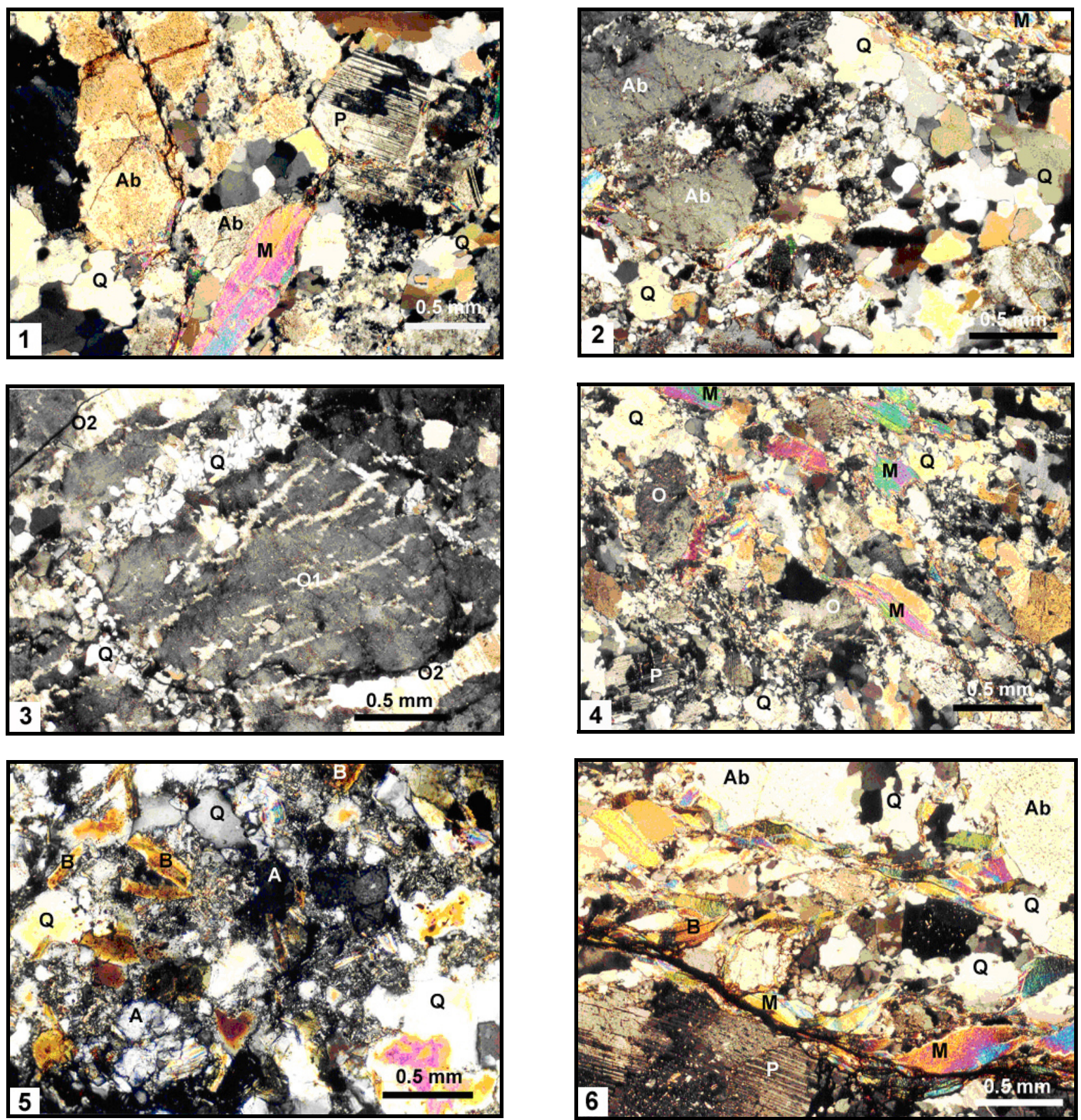

Plate I

Fig. 1. Cataclastic granite with injections of late quartz. Quartz (Q), feldspars: plagioclases (first generation) (P), albite (second generation) $(A b)$, and muscovite (M). Sample 12, block 4. $N^{+}$

Fig. 2. Cataclastic pegmatitic granite. Albite $(A b)$, quartz $(O)$, and muscovite $(M)$. Sample 8, block $6 . N+$

Fig. 3. Cataclastic pegmatitic granite. Orthoclase: perthitic exsolutions (O1), perthitic substitutions (O2), and diaclases filled with quartz (Q). Sample 1, block 16. $N^{+}$

Fig. 4. Granitic gneiss. Quartz (Q), plagioclase feldspars $(P)$, orthoclase $(O)$, muscovite and biotite (M) Sample 9, block 15. $N^{+}$

Fig. 5. Biotite hornfels. Quartz (Q), biotite (B), and apatite (A). Sample 6, block 16. $N+$

Fig. 6. Granitic gneiss. Quartz $(Q)$ - albite $(A b)$ neosome in biotite $(B)$ - muscovite $(M)$ micaschist with plagioclase $(P)$, and almandine Sample 5, block 16. N+ 